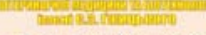

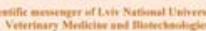

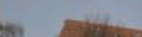
$\sqrt{11} \mathrm{kin}$

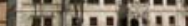

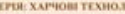
Том $21 \mathrm{Na} 91$
Науковий вісник Яьвівського національного університету ветеринарної медицини та біотехнологій імені С.3. Гжицького. Серія: Харчові технології

\author{
Scientific Messenger of Lviv National University
} of Veterinary Medicine and Biotechnologies.

Series: Food Technologies

ISSN 2519-268X print

https://nvlvet.com.ua/index.php/food

UDC 664.92

\title{
Analysis of innovative technologies of hydrogels from uronate polysaccharides and biodegradable films on their basis
}

\author{
N.V. Kondratiuk ${ }^{1}$, T.M. Stepanova ${ }^{2}$, O.O. Chernushenko ${ }^{1}$ \\ ${ }^{1}$ Oles Honchar Dnipro National University, Dnipro, Ukraine \\ ${ }^{2}$ Sumy National Agrarian University, Sumy, Ukraine
}

Article info

Received 28.01.2019

Received in revised form 04.03 .2019

Accepted 05.03.2019

Oles Honchar Dnipro National University, Gagarin ave., 72 , Dnipro, 49010, Ukraine. Tel.: +38-097-918-20-09 E-mail: kondratjukn3105@gmail.com

Sumy National Agrarian University, Gerasyma Kondratyeva Str., 160 Sumy, 40021, Ukraine Tel.: +38-099-711-36-79 E-mail: eshkina97@gmail.com
Kondratiuk, N.V., Stepanova, T.M., \& Chernushenko, O.O. (2019). Analysis of innovative technologies of hydrogels from uronate polysaccharides and biodegradable films on their basis. Scientific Messenger of Lviv National University of Veterinary Medicine and Biotechnologies. Series: Food Technologies, 21(91), 100-103. doi: 10.32718/nvlvet-f9117

The article is devoted to the analysis of the state and dynamics of scientific developments in the field of creating products for life and health, based on hydrogels from uronate polysaccharides (HUP). The article is reflected the results of the global scientific research monitoring and their changes in the field of technologies for the creation and use of HUP. The results of a retrospective analysis of existing technologies based on poorly studied in the field of food technologies uronic acids, as glucuronic, idouronic, hyaluronic were presented. The study showed, that nowadays the industry of products with their content is acquiring market traits, although it has insufficient scientific substantiation. Development segments with widely used uronate polysaccharides - pectins and alginates - according to the types of hydrogels (swollen hydrogel, crosslinked hydrogel, xerogel) were developed. The article presents examples and identified the required properties of substances intended for immobilization or encapsulation in the hydrogel matrix of uronate polysaccharides. The basic principles of uronate polysaccharides crosslinking chains in the hydrogel phase are determined. Possible methods of biologically active substances (BAS) retention in the matrix of uronate polysaccharides to reduce the risk of premature oxidation, destruction, decomposition, decomposition, evaporation were described. The search for information allowed us to identify key technological areas for the development of scientific research on the creation and use of HUP to improve people's lives and health. The archives of the world's leading publications in the field of food chemistry, biotechnology, food engineering, chemistry of new materials, food polymers and hydrocolloids were analyzed. The authors used in their work the resources of the Science Direct search system, which made it possible to determine the most promising and modern lines of development of HUP technologies and products based on them. The analysis of technologies has shown that existing innovative technologies are formed on "basic" technologies for producing solutions of high-molecular compounds under various conditions. Active modernization is carried out in the direction of creating products with immobilized biologically active substances, as well as in attempts to compose a composition with other polysaccharides and/or peptide components. The article notes that existing technologies allow developing other technologies with the help of which it is possible to expand the field of HUP application.

Key words: uronate polysaccharides, alginate, pectin, xanthan, hyaluronic acid, hydrogels, immobilization, "cross-copolymerization".

\section{Анализ инновационных технологий гидрогелей из уронатных полисахаридов и биодеградирующих пленок на их основе}

\author{
Н.В. Кондратюк ${ }^{1}$, Т.М. Степанова ${ }^{2}$, Е.А. Чернушенко ${ }^{1}$ \\ ${ }^{1}$ Днипровский наџиональный университет имени Олеся Гончара, г. Днипро, Украина \\ ${ }^{2}$ Сумский нацииональный аграрный университет, г. Сумыл, Украина
}


Статья посвящена анализу состояния и динамике научных разработок в области создания продуктов для жизни и здоровья на основе гидрогелей из уронатных полисахаридов (ГУП). В статье отражень результаты мониторинга мировых научных исследований и их изменений в области технологий создания и применения ГУП. Авторы представили результаты ретроспективного анализа существующих технологий на основе малоизученых в области пищевых технологий уроновых кислот: глюкуроновая, идоуроновая, гиалуроновая. Исследование показало, что на сегодня индустрия продуктов с их содержанием приобретает вполне рыночные черты, хотя и имеет недостаточно полное научное обоснование. Сформированы сегменты разработок с иироко используемыми уронатными полисахаридами - пектинами и альгинатами - по видам гидрогелей (гидрогель набухиий, гидрогель сиитьй, ксерогель). В статье представлены примеры и выявлены требуемые свойства веществ, предназначенных для иммобилизации или инкапсулячии в матрицу гидрогеля из уронатных полисахаридов. Определены основные принципы сшивания иепочек уронатных полисахаридов в фазе гидрогеля. Описаны возможные способы удержания биологически активньх веществ (БАВ) в матрице уронатных полисахаридов для снижения риска преждевременного окисления, деструкции, разложения, распада, испарения. Поиск информации позволил определить ключевые технологические области развития научных исследований по созданию и применению ГУП для улучшения жизни и здоровья людей. Проанализированы архивы ведущих мировых изданий в области пищевой химии, биотехнологии, пищевой инженерии, химии новых материалов, пищевых полимеров и гидроколлоидов. Авторы использовали в работе ресурсы поисковой системы Sciепсе Direct, что позволило определить наиболее перспективные и современные направления развития технологий ГУП и продуктов на их основе. Анализ технологий показал, что сущцествующие инновационные технологии сформированы на “базисных" технологиях получения растворов высокомолекулярных соединений при различных условиях. Активная модернизация проводится в направлении создания продуктов с иммобилизированными БАВ, а также в попьтках составить композицию с другими полисахаридами и/или пептидными составляюшими. В работе отмечается, что существующие технологии позволяют развивать другие технологии, с помощью которых возможно расширить сферы применения ГУП.

Ключевые слова: уронатные полисахариды, альгинат, пектин, ксантан, гиалуроновая кислота, гидрогели, иммобилизация, “стоss-сополимеризация”.

\section{Introduction}

Relevance of the work. "Hydrogels" are cross-linked polymeric materials that are used in the fields of science and technology, as well as in the industry associated with the extraction and processing of minerals and food resources. New features of hydrogels are used in industries related to human health and aesthetics.

The concept of "hydrogels" was first used by Wichterle and Lim in 1954 (Kokkarachedu et al., 2017). The concept of "hydrogels based on uronate polysaccharides" (HUP) was recently proposed (Kondratiuk \& Pyvovarov, 2017). This is due to the fact that new possibilities of these systems in the food industry were discovered. It is the working name of the scientific cluster during the creating semi-finished and finished products based on the principle of ionotropic gelation with the possibility of phase transformations. HUP represent the frame, twophase systems, cross-linked together by various "crosscopolymers". Their role can be played by water molecules, calcium ions, amino acids, organic acids, peptides (including short-chain ones), hydrolysates, polyunsaturated fatty acids, oligomers, vitamins, flavonoids and other biologically active substances (BAS) (Kondratiuk et al., 2017; 2018). The interaction between the polymer chains of uronate polysaccharides and water is carried out through capillary, osmotic, hydrogen and Van der Waals forces, with the expansion of the chains of uronate polysaccharides and the formation of the socalled "pores". Reactively capable functional groups are arranged along the contour of such cells. These functional groups have partially positive $\left(-\mathrm{CH}_{3},-\mathrm{NH}_{2}\right)$ either partially negative charge $\left(-\mathrm{COOH},-\mathrm{COH},-\mathrm{CO},-\mathrm{CH}_{2} \mathrm{OH}\right)$. This allows the immobilization of biologically active substances by means of electrostatic attraction forces.

All processes come into dynamic equilibrium at the last stage of the such "cross-copolymer" structures formation. This state of hydrogel equilibrium depends on the magnitude of these opposite effects. These opposite effects determine the rheological and technological properties of hydrogels, including internal molecule transport, diffusion characteristics and mechanical strength..

This predetermined new approaches to using HUP as matrices with unique properties and characteristics.

The purpose and objectives of the study.

The purpose of this article is to analyze the scientific literature in the field of the possibility of using hydrogels based on uronate polysaccharides in food production technologies.

The main task of the article is a retrospective analysis of the state and dynamics of researches related to the development of technologies based on the HUP; identification of key technological directions for the market development of products based on the HUP; analysis of basic technologies in order to develop innovations in the program of providing the population with high-quality products and health-improving action.

\section{Results and discussion}

Hydrogels are used for food additives, pharmaceuticals, biomedical implants, tissue engineering and regenerative drugs, diagnosis of diseases, cell encapsulation, as barrier materials for the regulation of biological adhesion, biosensors and biomedical microelectromechanical devices. Their range of applications has expanded to the creation of artificial muscles, controlled drug delivery, the production of contact lenses and other ophthalmic positions, dressings and superabsorbents (Kokkarachedu et al., 2017). Recently, hydrogels have become potential contenders for the creation of intelligent functional materials.

After analyzing the existing information on this issue, we made a fundamental conclusion: the unique properties and enormous capabilities of hydrogels lie in the uniformity of the chemical nature of the uronate polysaccharides, namely, sodium alginate, pectin, xanthan and hyaluronic acid. A wide range of applications is based on the possibility of combining them with other polysaccharides, such as chitosan, guar, cellulose, starches, as well as proteins: whey proteins, gelatin, 
collagen and elastin. The combination is based on the principles of macromolecules crosslinking with each other with the participation of water molecules..

The authors (Laís et al., 2018) investigated the processes of "cross-copolymerization" in the system "chitosan-pectin".

They found that the crosslinking of two polysaccharides occurs through the formation of an ionic bond between the amino group of chitosan $\left(-\mathrm{NH}_{3}{ }^{+}\right)$and carboxyl group of galacturonic acid in pectin $\left(-\mathrm{COO}^{-}\right)$. Most of all these particles are formed in protonated surroundings. According to these authors, such systems allow to obtain durable, but elastic films to ensure the prolongation of the food quality, for example, meat.

A group of authors studied the processes of crosslinking xanthan with glycerol (Bilanovic et al., 2016). Three new phases were obtained based on the described model in addition to hydrogels, as foams, aerogels and films. Developers position objects as food systems intended for non-meat users. However, the evidence base of this issue in this article is missing.

The results presented in the paper (Karača et al., 2019) became interesting. They show the possibility of the food films formation based on the combined "alginate-pectin" hydrogel with the Helichrysum italicum extract as a source of polyphenols in the matrix, which can reduce microbial contamination on the surface of food products, that are placed in such films.

The authors also considered the possibility of adding protein (soybean, whey protein isolate and cannabis protein) to the hydrogel, but the attempt was not successful and requires further work.

It is important to state a successful attempt to introduce and retain the extract in the composition of the hydrogel, since this makes it possible to expand the range of research in this particular direction.

The authors of (Bušić et al., 2018) presented the results of a study in which alginate hydrogels were used to immobilize biologically active compounds. However, the authors report that the structure of the alginate gel network is very porous and mainly results in a high diffusion rate of the immobilized substance, which reduces its effectiveness as a delivery matrix. To prevent the loss of biologically active substances and the preparation of effective immobilization, the use of fillers, cocoa powder, and carob powder is proposed. Dandelion leaf extract (Taraxacum officinale L.) was used as an immobilizing substance. Also, whey protein isolate was used as a filler.

Based on the studies conducted, the authors state that using whey protein in alginate provides a better way to retain polyphenols $(>93 \%)$ than new binary systems based on alginate with cocoa free and carob $(>88 \%)$. It was also shown that the alginate-cocoa powder system prepared with a lower concentration of calcium chloride $\left(\begin{array}{lll}2 \% & \mathrm{CaCl}_{2}\end{array}\right)$ provides the longest release of total polyphenols and hydroxycinnamic acids. The results obtained open up new directions for the design of binary carriers of biologically active substances and the convincingly reasonable application of new plant functional fillers, such as cocoa powder and carob for the immobilization of flavonoids.
A group of researchers provides the results of work (Gomez et al., 2006) on the creation of alginate-chitin matrices intended for immobilization of an enzyme of the invertase class, Saccharomyces cerevisiae, which has previously undergone chemical modification with chitosan. The researchers cite data that the output of the immobilized protein object was $85 \%$, and the activity was $97 \%$ of the initial value.

An interesting fact is that an increase in the thermal stability of the immobilized enzyme by about $9{ }^{\circ} \mathrm{C}$ was noted. The immobilized enzyme was also resistant to incubation in solutions with high ionic strength and was four times more resistant to heat treatment at $65^{\circ} \mathrm{C}$ than the native counterpart.

Interesting also can be noted the results of a study given in (Liu et al., 2019). The authors have produced and described alginate matrices combined with sodium caseinate, to which curcumin has been added. Fourier transform infrared spectroscopy (FTIR), scanning electron microscopy (SEM) and surface hydrophobicity measurements showed that the hydrophilic sodium caseinate and sodium alginate particles are absorbed by the upper layers of the zein - curcumin complex through electrostatic interaction, which increases their dissolution in water. Immobilization of curcumin in composite nanoparticles not only significantly improved photochemical stability, but also provided controlled release under conditions of imitation of the gastrointestinal tract. The authors suggested that the resulting composite nanoparticles would be used as a carrier for the delivery of chemically unstable hydrophobic active compounds in the food and pharmaceutical industries.

In article (Enas, 2015), a broad analytical review of the applications of polysaccharide-based hydrogels, including uronate ones, is presented, but the food industry is not presented. However, the work presents the classification of hydrogels depending on the main components, physicochemical characteristics of hydrogels and the technical possibility of their use. The article also presents production technologies, describes the conditions for designing the process and building a flowchart, and offers suggestions on how to optimize the process of preparing objects for research, which is especially important for reorganizing workshops at food factories that include such innovations in the production cycle.

\section{Conclusions}

During the analysis of literature sources, special attention was paid to the innovative direction of using hydrogels as part of food systems. An approach to optimizing information flows based on the explanation of chemical interactions and phase transitions was important. This allows us to understand the many-sided nature of the HUP and the principles of innovations formation in the field of food technologies.

Prospects for further research. Immobilization into the hydrogels on the basis of uronate polysaccharides matrix amino acids, vitamins and other biologically active substances extracts is a unique strategy in creating of food products that regulate and improve metabolism. Based on 
this strategy, it is possible to develop new technologies for food products that retain unique properties even with long storage periods.

\section{References}

Bilanovic, D., Starosvetsky, J., \& Armon, R.H. (2016). Preparation of biodegradable xanthan-glycerol hydrogel, foam, film, aerogel and xerogel at room temperature. Carbohydrate Polymers, 148, 243-250. doi: 10.1016/j.carbpol.2016.04.058.

Bušić, A., Belščak-Cvitanović, A., \& Cebin, A.V. (2018). Structuring new alginate network aimed for delivery of dandelion (Taraxacum officinale L.) polyphenols using ionic gelation and new filler materials. Food Research International, 111, 244-255. doi: 10.1016/j.foodres.2018.05.034.

Enas, M.A. (2015). Hydrogel: Preparation, characterization, and applications: A review Journal of Advanced Research, 6, 105-121 doi: 10.1016/j.jare.2013.07.006.

Gomez, L., Ramirez, H.L., Villalonga, M.L., \& Hernandez, J. (2006). Immobilization of chitosan-modified invertase on alginate-coated chitin support via polyelectrolyte complex formation. Enzyme and Microbial Technology, 38, 22-27. doi: 10.1016/j.enzmictec.2004.10.008.

Karača, S., Trifković, K., Bušić, A., \& Dordević, V. (2019). The functional potential of immortelle (Helichrysum italicum) based edible films reinforced with proteins and hydrogel particles. Food Science and Technology, 99, 387-395. doi: 10.1016/j.lwt.2018.09.039.

Kokkarachedu, V., Gownolla, M.R., \& Tippabattini, J. (2017). A mini review on hydrogels classification and recent developments in miscellaneous applications. Materials Science and Engineering, 79, 958-971. doi: 10.1016/j.msec.2017.05.096.
Kondratiuk, N.V., \& Pyvovarov, Ye.P. (2017). Kharchovi uronatni hidroheli yak osnova stratehii zdorovoho kharchuvannia u zakladakh restorannoho hospodarstva. Aktualni problemy rozvytku restorannoho, hotelnoho ta turystychnoho biznesu $\mathrm{v}$ umovakh svitovoi intehratsii: doslidzhennia ta perspektyvy (in Ukrainian).

Kondratiuk, N.V., Mulyk, R.Y., \& Polyvanov, Y.A. (2017). New prospects for making food gels based on uronic polysaccharides. III International Scientific and Practical-Conference "Modern Methodology of Science and Education”, 6(22), 1, 48-50.

Kondratiuk, N.V., Stepanova, T.M., \& Toloshnyi, D.V. (2018). Heli kharchovi plivkoutvoriuiuchi na osnovi uronatnykh polisakharydiv u vyrobnytstvi sumishei dlia iniektuvannia miasoproduktiv. Vcheni zapysky TNU imeni V.I. Vernadskoho. Seriia: tekhnichni nauky, 29(68), 20-25 (in Ukrainian).

Kondratiuk, N.V., Stepanova, T.M., \& Burak, V.G. (2018). The food envelop forming coatings using on the basis of uronate polysaccharides in manufacture of chocolate products with protein hydrolyzate. The development of technical sciences: problems and solutions: Conference Proceedings, April 27-28, Brno: Baltija Publishing, 53-56.

Laís, B.N., Juliano, E.O., Francys, K.V., \& Moreira, J.M. (2018). Rheological and thermo-mechanical evaluation of bio-based chitosan/pectin blends with tunable ionic cross-linking. International Journal of Biological Macromolecules, 118, 1817-1823. doi: 10.1016/j.ijbiomac.2018.07.027.

Liu, Q., Jing, Y., Han, C., Zhang, H., \& Tian, Y., (2019). Encapsulation of curcumin in zein/ caseinate/sodium alginate nanoparticles with improved physicochemical and controlled release properties. Food Hydrocolloids, 93, 432-442. doi: 10.1016/j.foodhyd.2019.02.003. 